\title{
Year-class variations of American plaice Hippoglossoides platessoides ) and yellowtail flounder (Limanda ferruginea) in the Grand Banks and the abundance of other commercial fish
}

\author{
J. Paz and M.G. Larrañeta \\ Instituto de lnvestigaciones Marinas, Eduardo Cabello 6, 36208, Vigo, Spain \\ Correspondence to: J. Paz, Instituto de Investigaciones Marinas, Eduardo Cabello 6, \\ 36208, Vigo, Spain.
}

\begin{abstract}
Paz, J. and Larrañeta, M.G., 1992. Year-class variations of American plaice (Hippoglossoides platessoides) and yellowtail flounder (Limanda ferruginea) in the Grand Banks and the abundance of other commercial fish. Fish. Res., 15:121- 133.
\end{abstract}

The present study analyses the relationships between the recruitment of a species and adult populations of other species. The hypothesis is that reproduction products of some species may be food for the first stages of other species. In a previous paper we obtained a significant positive correlation between cod year-class size in NAFO Div. 3NO and American plaice spawning biomass in Div. 3LNO. Following the same method in this study, positive and significant correlations between plaice recruitment and yellowtail flounder, mackerel and redfish adult biomass values were found, but not between yellowtail recruitment and adult biomass values of the other species studied. These results agree with the idea that the American plaice is an integral component of the Grand Bank ecosystem.

\section{INTRODUCTION}

The population dynamics of a single species is regulated, in part, by the success of recruitment. Why recruitment varies is a complex question, which includes parental feeding and biotic and abiotic environmental factors during the pre-recruitment phase. One way to approach this problem is to study how the pre-recruits of one species are affected either directly or through their progeny, by adults of another species. Year-class 
size variation is usually studied by analysing the stock-recruitment relationship in isolation from any dependence on adult populations of other fish species. In this paper, this aspect of recruitment is examined.

Our hypothesis is that if two fish species spawn in the same area at the same time, or with a time lag less than the pelagic period of the earlier spawning species, the reproductive products (eggs and larvae) of one species may become an important food item for the other species, and have a significant effect on its survival rate. In a previous paper (Paz and Larrañeta, 1989) we obtained a significant positive correlation between cod year-class size in Div. $3 \mathrm{NO}$ and American plaice spawning biomass in Div. 3LNO. We suggested that this result indicated significant predation by O-group cod on O-group American plaice. In contrast, we have not found significant correlations between cod year-classes and adult biomass values of other species in the area, such as redfish, yellowtail flounder and mackerel.

The same method was used in this study to explore relations between American plaice (Hippoglossoides platessoides) and yellowtail flounder (Limanda ferruginea) year-class sizes and the biomass values of adults of these species and those of cod (Gadus morhua), mackerel (Scomber scombrus) and redfish (Sebastes spp.). Adults of these species, except mackerel, are not considered to be predators of eggs and larvae of plaice and yellowtail, though they can be of their young. The biomass values of adults are used as indices of their egg and larval abundances, as the reverse supposition, that egg abundance is an index of adult abundance, is usually accepted.

\section{MATERIAL AND METHODS}

Data on American plaice recruitment $\left(\mathrm{N}_{5}\right)$ and spawning biomass $\left(\mathrm{B}_{11+}\right)$ in Div. 3LNO have been taken from Brodie (1989), yellowtail flounder recruitment $\left(\mathrm{N}_{4}\right)$ and spawning biomass $\left(\mathrm{B}_{6+}\right)$ in Div. 3LNO from Brodie and Walsh (1988), cod spawning biomass $\left(\mathrm{B}_{6+}\right)$ in Div. 3NO from Baird and Bishop (1989), mackerel biomass (Labrador to North Carolina) from figure 19.1 in Anonymous (1986) and nominal redfish catches in Div. 3LN from Atkinson and Power (1971). These catches were considered as abundance indices of this population. All data are shown in Table 1 . The possibility of trophic relationships between O-group and juveniles of plaice, yellowtail and other species has 
been explored by relating the year-class sizes of these species, to the adult biomass values of the other species, from 1 to 3 years before (positive lag) or after (negative lag) the year of the plaice and yellowtail year-classes (Fig. 1). The plaice and yellowtail year-classes are also related to the adult spawning biomass values, which gave rise to them, and to their spawning biomass values lagged from 1 to 3 years before or after. The year-class is estimated at the time of recruitment, for plaice $\left(\mathrm{N}_{5}\right)$ and for yellowtail $\left(\mathrm{N}_{4}\right)$.

\section{RESULTS}

Correlations between plaice recruitment and its spawning biomass are shown in Table 2 , and those between yellowtail recruitment and its spawning biomass in Table 3; the only positive and significant correlations are with -2 and -3 year lags for plaice.

The correlation coefficients between plaice recruitment and yellowtail spawning biomass are shown in Table 4; positive coefficients appear with 0,1 and 2 year lags. The regression line for the 0 year lag is shown in Fig. 2. There is no significant correlation between plaice recruitment and cod spawning biomass (Table 5). However, positive and highly significant correlations appear between plaice recruitment and mackerel biomass with 0,1 and 2 year lags (Table 6). The regression line for the 0 year lag is shown in Fig. 3. Likewise, there was a positive and significant correlation between plaice recruitment and redfish catches with a 1 year lag (Table 7).

No significant correlation coefficients appear between yellowtail recruitment and plaice, cod, mackerel and redfish biomass values (Tables 8-11).

Finally, Table 12 shows the linear regression parameters when correlations have a $\mathrm{P}$ value equal to or less than 0.01 .

\section{DISCUSSION}

The map of the NAFO convention area is shown in Fig. 4 and the spawning times and locations for the species studied in the Grand Banks region are shown in Fig. 5(a) and $5(b)$. 
There were no significant correlations between plaice and yellowtail recruitment and their spawning biomass values (0-year lag in Tables 2 and 3). We could find no immediate explanation for correlations for plaice with -2 and -3 year lags (Table 2).

The positive correlation (Table 4) between plaice recruitment and yellowtail spawning biomass suggests that O-group plaice prey on yellowtail eggs and larvae; in the Grand Banks, the plaice spawning peak occurs in late April (Pitt, 1966) and the yellowtail peak occurs in late June (Pitt, 1970). Plaice eggs hatch 11-14 days after spawning at $4^{\circ} \mathrm{C}$ (Scott and Scott, 1988) and metamorphosis in Pleuronectes platessa, a related species, takes place 120-130 days after spawning (Bannister et al., 1974). Yellowtail eggs hatch 5 days after spawning at $10-11^{\circ} \mathrm{C}$ (Scott and Scott, 1988). We have no other explanation for the significant correlations in Table 4 where the 1 and 2 year lags indicate that there will be similar levels of yellowtail spawning biomass for 3 consecutive years.

It does not seem possible to interpret the positive and strongly significant correlation between plaice recruitment and mackerel biomass with 0,1 and 2 year lags (Table 6) by supposing predation of 0-, 1- and 2-group plaice on O-group mackerel. The O-group mackerel have fast growth rates and are active predators on the eggs and larvae of other fish species; they are also cannibalistic. On the other hand, 1- and 2-group plaice are demersal, hence far from the neustonic zone which mackerel inhabit. Mackerel and plaice spawning areas are also distinct (Gulf of St. Lawrence and Div. 3N, respectively). However, during the winter-spring season, adult mackerel extend to Div. 3NO, and the peak spawning period is in late June and early July. It may be that adult mackerel prey are important predators of O-group plaice. In our experience, 0-3 year old mackerel off northwest Spain prey especially on juvenile decapod crustaceans, and when older, on fish (Micromesistius poutassou) and adult macrurids. Also, according to Van der Verr et al. (1990), predation by crustaceans (Crangon crangon and Carcinus maenas) is the main source of mortality of O-group Pleuronectes platessa in the nursery areas of the Wadden Sea and in Swedish waters. In spring, these crustaceans prey on O-group plaice up to $3 \mathrm{~cm}$ long, during the period of settlement, and regulate the plaice population. The significant correlation between mackerel biomass and American plaice recruitment, therefore, may indicate that abundant mackerel reduce the biomass of some benthic 
predator, and hence reduce the mortality imposed on O-group plaice during the settlement period.

There is no obvious reason for the positive correlation between plaice recruitment and redfish biomass with 1 and 2 year lags (Table 7). Although redfish larvae occur at $200 \mathrm{~m}$ or more on the shelf edge (Bainbridge and Cooper, 1971; Akenhead, 1987), it seems unlikely that redfish larvae are eaten to any great extent by 1-group plaice. In general, there are no significant correlations between yellowtail recruitment and the adult biomass values of the other species studied.

We have seen that the recruitment of some species (species A) is related to the adult abundance of other species (species B). Our hypothesis is that the O-group fish of species A prey on the O-group fish of species B. However, the recruitment values of species B are not related to the abundance of species A adults. These species pairs are cod (A)-plaice (B) and plaice (A)-yellowtail (B). Let us suppose that good recruitment is brought about by the survival of 100 eggs per female, and bad recruitment by one egg per female. The relationship between good and bad survival rates will be $S_{g} / S_{b}=100$, whilst the relationship between mortality rates will be $1-\mathrm{S}_{\mathrm{g}} / 1-\mathrm{S}_{\mathrm{b}} \approx 1$. That is to say, good survival due to adequate feeding may be a more important factor affecting recruitment than mortality caused by predation.

To summarise, positive and significant correlations were found between plaice recruitment and yellowtail, mackerel and redfish adult biomass values, but not between yellowtail recruitment and the adult biomass values of other species studied (Table 13) This seems to be consistent with the idea that Div. 3LNO represents the core area of American plaice in the Northwest Atlantic, and it will therefore be a very integrated species in the Grand Bank ecosystem. In this way, plaice population dynamics could depend very much on biotic factors in this area. This view agrees with the important contribution of plaice assemblages on the Grand Bank (Gomes et al., 1989). However, yellowtail has been a fishery resource in this area only since the second half of the 1960s (Anonymous, 1975). Pitt (1970) suggested that the rapid increase in yellowtail abundance was related to an increase in bottom temperatures and a drastic reduction brought about by fishing in the size of haddock stocks, which were apparently competitors of yellowtail. In any case, the yellowtail distribution centre is south of the 
Grand Banks, so that its integration into the dynamics of the ecosystem may be less complete, and its abundance depend more on physical factors than on biotic ones.

\section{REFERENCES}

Akenhead, S.A., 1987. Diffusion and redfish larvae on Flemish Cap. Can. Tech. Rep. Fish. Aquat. Sci., 1556, iv +65 pp.

Anonymous, 1975. Statistical Bulletin for the year 1973. Vol. 23. ICNAF, Darmouth, Canada, 277 pp.

Anonymous, 1986. Status of the fishery resources off the northeastern United States for 1986. NOAA Tech. Men. MNFS/NEC 43, 130 pp.

Atkinson, D.B. and Power, D., 1971. Redfish in NAFO Divisions 3LN. NAFO SCR Doc. No. 54, Serial No. 1634, NAFO, 26 pp.

Bainbridge, V. and Cooper, G.A., 1971. Population of Sebastes larvae in the North Atlantic. Res. Bull. ICNAF, 8, pp. 27-35.

Baird, J.W. and Bishop, C.A., 1989. The assessment of the cod stock in NAFO Div. 3NO. NAFO SCR Doc. No. 35, Serial No. 1611, NAFO, 61 pp.

Bannister, R.C.A., Harding, D. and Lockwood, S.J., 1974. Larval mortality and subsequent year-class strength in the plaice (Pleuronectes platessa, L.). In: J.H.S. Blaxter (Editor), The Early History Fish (Oban, 1973). Springer, Berlin, pp. 21-32.

Brodie, W.B., 1989. An assessment of the American plaice stock in Division 3LNO. NAFO SCR Doc. No. 37, Serial No. 1477, NAFO, 51 pp.

Brodie, W.B. and Walsh, S.J., 1988. An update on the status of yellowtail flounder stock in Division 3LNO. NAFO SCR Doc. No. 38, Serial No. 1478, NAFO, 42 pp.

Fitzpatrick, C. and Miller, R.J., 1979. Review of spawning times and locations for some commercial finfish on the Newfoundland and Labrador coasts. Fish. Mar. Serv. Tech. Rep. 905, v 14 pp.

Gomes, M.C., Haedrich, R. and Rice, J.C., 1989. Fish assemblages on the Grand Bank of Newfoundland. NAFO SCR Doc. No. 89, Serial No. 1656, NAFO, 31 pp.

Paz, J. and Larrañeta, M.G., 1989. Cod in Div 3NO: year-class variations and the abundance of other commercial fish. NAFO SCR Doc. No. 72, Serial No. 1653, NAFO, 9 pp. 
Pitt, T.K., 1966. Sexual maturity and spawning of the American plaice, Hippoglossides platessoides (Fabricius), from Newfoundland and the Grand Bank areas. J. Fish. Res. Board Can., 23: 651-672.

Pitt, T.K., 1970. Distribution abundance and spawning of yellowtail flounder, Limanda ferruginea, in the Newfoundland area of northwest Atlantic. J. Fish. Res. Board Can., 27: 2261-2271.

Scott, W.B. and Scott, M.G., 1988. Atlantic fishes of Canada. Can. Bull. Fish. Aquat. Sci., 219: 713 pp.

Van der Verr, H.W., Pihl, L. and Bergman, M.J.N., 1990. Recruitment mechanisms in the North Sea Pleuronectes platessa. Mar. Ecol. Prog. Ser., 64:1-12. 


\section{TABLE 1}

American plaice Div. 3LNO spawning stock biomass $\left(\mathrm{B}_{11+}\right)$ and recruitment $\left(\mathrm{N}_{5}\right)$ from Brodie (1988). Yellowtail flounder Div. 3LNO: recruitment $\left(\mathrm{N}_{4}\right)$ and spawning stock biomass $\left(\mathrm{B}_{6+}\right)$, from table 4 of Brodie and Walsh (1988). Cod Div. 3NO: spawning biomass $\left(\mathrm{B}_{6+}\right)$, from Baird and Bishop (1989). Mackerel Labrador-North Carolina: population biomass $\left(\mathrm{B}_{1+}\right)$, from figure 19.1 of Anonymous (1986). Redfish Div. 3LN: minimal catches from Atkinson and Power (1989)

\begin{tabular}{|c|c|c|c|c|c|c|c|}
\hline $\begin{array}{l}\text { Year- } \\
\text { class }\end{array}$ & $\begin{array}{l}\text { A. plaice } \\
\mathrm{B}_{11+}\end{array}$ & $\mathrm{N}_{5}$ & $\begin{array}{l}\text { Y. flounder } \\
\mathrm{B}_{6+}\end{array}$ & $\mathrm{N}_{4}$ & $\begin{array}{l}\text { Cod } \\
\mathrm{B}_{6+}\end{array}$ & $\begin{array}{l}\text { Mackerel } \\
\mathrm{B}_{1+}\end{array}$ & $\begin{array}{l}\text { Refish } \\
\text { catch }\end{array}$ \\
\hline 1956 & - & - & - & - & - & - & - \\
\hline 1957 & - & - & - & - & - & - & - \\
\hline 1958 & - & - & - & - & - & - & - \\
\hline 1959 & - & - & - & - & 8840 & - & 10478 \\
\hline 1960 & - & 236421 & - & - & 7234 & - & 16547 \\
\hline 1961 & - & 211435 & - & - & 8974 & - & 14826 \\
\hline 1962 & - & 189939 & - & - & 8032 & - & 18009 \\
\hline 1963 & - & 149426 & - & - & 8787 & 275 & 12906 \\
\hline 1964 & - & 146251 & - & 156799 & 11264 & 311 & 4206 \\
\hline 1965 & 138197 & 138500 & - & 147013 & 12015 & 323 & 4042 \\
\hline 1966 & 158756 & 177331 & - & 119893 & 10462 & 371 & 10047 \\
\hline 1967 & 157325 & 220607 & - & 110606 & 9344 & 623 & 19504 \\
\hline 1968 & 158837 & 269745 & 25926 & 121785 & 8268 & 1198 & 14265 \\
\hline 1969 & 120238 & 261976 & 40372 & 113144 & 8026 & 1533 & 22142 \\
\hline 1970 & 94378 & 274795 & 50199 & 75673 & 8137 & 1856 & 13359 \\
\hline 1971 & 81403 & 259997 & 48747 & 71659 & 8819 & 1868 & 24310 \\
\hline 1972 & 62129 & 216563 & 33846 & 79483 & 7812 & 1653 & 25838 \\
\hline 1973 & 52619 & 203490 & 24049 & 83973 & 7618 & 1389 & 25588 \\
\hline 1974 & 50889 & 187753 & 21034 & 86856 & 5373 & 1126 & 10867 \\
\hline 1975 & 45906 & 177919 & 18159 & 70496 & 1929 & 970 & 14033 \\
\hline 1976 & 39864 & 175574 & 19152 & 68298 & 1233 & 719 & 4541 \\
\hline 1977 & 45515 & 216181 & 18809 & 121448 & 1655 & 491 & 3065 \\
\hline 1978 & 48818 & 206101 & 21776 & 175222 & 1948 & 467 & 5725 \\
\hline 1979 & 60846 & 170123 & 17415 & 168279 & 2628 & 503 & 8483 \\
\hline
\end{tabular}




\begin{tabular}{llllllll}
\hline 1980 & 67125 & 178060 & 26325 & 88426 & 5713 & 467 & 11663 \\
1981 & 53278 & 255564 & 20530 & 55605 & 8830 & 479 & 14873 \\
1982 & 46852 & - & 16098 & 12925 & 9152 & 599 & 13677 \\
1983 & 42294 & - & 28755 & - & 10004 & 695 & 11090 \\
1984 & 46090 & - & 44789 & - & 9556 & 1078 & 12065 \\
1985 & 56357 & - & 50805 & - & 10305 & - & 16880 \\
1986 & 42383 & - & 31474 & - & 11069 & - & 14971 \\
1987 & - & - & - & - & 10990 & - & - \\
1988 & - & - & - & - & 9120 & - & - \\
\hline
\end{tabular}

TABLE 2

Correlation coefficients between plaice recruitment and plaice spawning biomass

\begin{tabular}{|c|c|c|c|c|c|c|c|}
\hline \multicolumn{8}{|c|}{ Lag } \\
\hline & -3 & -2 & -1 & 0 & 1 & 2 & 3 \\
\hline $\mathrm{n}$ & 14 & 15 & 16 & 17 & 18 & 19 & 20 \\
\hline $\mathrm{r}$ & 0.763 & 0.784 & 0.555 & 0.132 & -0.193 & -0.422 & -0.514 \\
\hline $\mathrm{P}$ & 0.001 & $<0.001$ & 0.024 & 0.618 & 0.450 & 0.072 & 0.019 \\
\hline
\end{tabular}

TABLE 3

Correlation coefficients between yellowtail recruitment and yellowtail spawning biomass

\begin{tabular}{llllllll}
\hline \multicolumn{2}{l}{ Lag } & \multicolumn{7}{l}{$l$} & \\
\cline { 2 - 7 } & -3 & -2 & -1 & 0 & 1 & 2 & 3 \\
\hline $\mathrm{n}$ & 12 & 13 & 14 & 15 & 16 & 17 & 18 \\
$\mathrm{r}$ & -0.170 & -0.268 & -0.228 & -0.081 & -0.022 & -0.72 & -0.227 \\
$\mathrm{P}$ & 0.606 & 0.385 & 0.442 & 0.779 & 0.936 & 0.788 & 0.370 \\
\hline
\end{tabular}

\section{TABLE 4}

Correlation coefficients between plaice recruitment and yellowtail spawning biomass

$$
\text { Lag }
$$




\begin{tabular}{llllllll}
\cline { 2 - 7 } & -3 & -2 & -1 & 0 & 1 & 2 & 3 \\
\hline $\mathrm{n}$ & 11 & 12 & 13 & 14 & 15 & 16 & 17 \\
$\mathrm{r}$ & -0.064 & 0.165 & 0.589 & 0.701 & 0.722 & 0.696 & 0.390 \\
$\mathrm{P}$ & 0.852 & 0.610 & 0.026 & 0.004 & 0.002 & 0.002 & 0.183 \\
\hline
\end{tabular}

\section{TABLE 5}

Correlation coefficients between plaice recruitment and cod spawning biomass

\begin{tabular}{llllllll}
\hline \multicolumn{2}{c}{ Lag } & \multicolumn{6}{l}{$l$} \\
\cline { 2 - 7 } & -3 & -2 & -1 & 0 & 1 & 2 & 3 \\
\hline $\mathrm{n}$ & 20 & 21 & 22 & 22 & 22 & 22 & 22 \\
$\mathrm{r}$ & 0.220 & 0.091 & 0.076 & 0.046 & -0.008 & -0.023 & -0.014 \\
$\mathrm{P}$ & 0.328 & 0.695 & 0.737 & 0.839 & 0.972 & 0.920 & 0.950 \\
\hline
\end{tabular}

TABLE 6

Correlation coefficients between plaice recruitment and mackerel population biomass

\begin{tabular}{llllllll}
\hline \multicolumn{2}{l}{ Lag } & \multicolumn{7}{l}{$l$} \\
\cline { 2 - 7 } & -3 & -2 & -1 & 0 & 1 & 2 & 3 \\
\hline $\mathrm{n}$ & 16 & 17 & 18 & 19 & 20 & 21 & 22 \\
$\mathrm{r}$ & -0.364 & 0.095 & 0.429 & 0.692 & 0.809 & 0.731 & 0.475 \\
$\mathrm{P}$ & 0.169 & 0.722 & 0.075 & 0.001 & $<0.001$ & $<0.001$ & 0.025 \\
\hline
\end{tabular}

TABLE7

Correlation coefficients between plaice recruitment and redfish biomass (catches)

\begin{tabular}{llllllll}
\hline \multicolumn{2}{c}{ Lag } & & & & & & \\
\cline { 2 - 7 } & -3 & -2 & -1 & 0 & 1 & 2 & 3 \\
\hline $\mathrm{n}$ & 20 & 21 & 22 & 22 & 22 & 22 & 22 \\
$\mathrm{r}$ & -0.061 & 0.035 & 0.271 & 0.515 & 0.624 & 0.542 & 0.386 \\
$\mathrm{P}$ & 0.270 & 0.880 & 0.225 & 0.015 & 0.003 & 0.010 & 0.056 \\
\hline
\end{tabular}


TABLE 8

Correlation coefficients between yellowtail recruitment and plaice spawning biomass

\begin{tabular}{llllllll}
\hline \multicolumn{2}{l}{ Lag } & \multicolumn{7}{l}{0} & & & & \\
\cline { 2 - 7 } & -3 & -2 & -1 & 0 & 1 & 2 & 3 \\
\hline $\mathrm{n}$ & 15 & 16 & 17 & 18 & 19 & 19 & 19 \\
$\mathrm{r}$ & -0.105 & -0.032 & 0.126 & 0.341 & 0.529 & 0.565 & 0.485 \\
$\mathrm{P}$ & 0.715 & 0.907 & 0.635 & 0.169 & 0.019 & 0.014 & 0.034 \\
\hline
\end{tabular}

\section{TABLE 9}

Correlation coefficients between yellowtail recruitment and cod spawning biomass

\begin{tabular}{llllllll}
\hline \multicolumn{2}{c}{ Lag } & & & & & & \\
\cline { 2 - 7 } & -3 & -2 & -1 & 0 & 1 & 2 & 3 \\
\hline $\mathrm{n}$ & 19 & 19 & 19 & 19 & 19 & 19 & 19 \\
$\mathrm{r}$ & -0.021 & 0.094 & 0.124 & 0.079 & 0.004 & 0.176 & 0.297 \\
$\mathrm{P}$ & 0.932 & 0.706 & 0.619 & 0.752 & 0.987 & 0.477 & 0.221 \\
\hline
\end{tabular}

\section{TABLE 10}

Correlation coefficients between yellowtail recruitment and mackerel spawning biomass

\begin{tabular}{llllllll}
\hline & Lag & & & & & & \\
\cline { 2 - 7 } & -3 & -2 & -1 & 0 & 1 & 2 & 3 \\
\hline $\mathrm{n}$ & 17 & 18 & 19 & 19 & 19 & 19 & 19 \\
$\mathrm{r}$ & -0.168 & 0.346 & 0.422 & 0.374 & 0.275 & 0.214 & 0.035 \\
$\mathrm{P}$ & 0.527 & 0.162 & 0.072 & 0.116 & 0.259 & 0.385 & 0.983 \\
\hline
\end{tabular}

\section{TABLE 11}

Correlation coefficients between yellowtail recruitment and redfish biomass (catches)

\begin{tabular}{llllllll}
\hline \multicolumn{2}{c}{ Lag } & & & & & & \\
\cline { 2 - 7 } & -3 & -2 & -1 & 0 & 1 & 2 & 3 \\
\hline $\mathrm{n}$ & 19 & 19 & 19 & 19 & 19 & 19 & 19 \\
$\mathrm{r}$ & -0.198 & -0.330 & -0.480 & 0.434 & -0.207 & 0.075 & 0.227 \\
\hline
\end{tabular}




\begin{tabular}{llllllll}
\hline $\mathrm{P}$ & 0.422 & 0.170 & 0.037 & 0.063 & 0.401 & 0.763 & 0.354
\end{tabular}

TABLE 12

Regression parameters, only when $\mathrm{P}<0.001$

\begin{tabular}{lllll}
\hline Biomass $\left(10^{3} \mathrm{t}\right) \mathrm{x}$ & Recruits $\left(10^{6}\right) \mathrm{y}$ & Lag & $\mathrm{a}$ & $\mathrm{b}$ \\
\hline Plaice & Plaice & -3 & 158.97 & 0.6677 \\
Plaice & Plaice & -2 & 160.70 & 0.6642 \\
Yellowtail & Plaice & 0 & 151.38 & 2.423 \\
Yellowtail & Plaice & 1 & 153.79 & 2.409 \\
Yellowtail & Plaice & 2 & 150.86 & 2.411 \\
Mackerel & Plaice & 0 & 157.08 & 0.0542 \\
Mackerel & Plaice & 1 & 149.18 & 0.0634 \\
Mackerel & Plaice & 2 & 155.33 & 0.0572 \\
Redfish & Plaice & 1 & 157.53 & 3.526 \\
\hline
\end{tabular}

TABLE 13

Significant correlations $(\mathrm{P}<0.01)$ between recruitment and population biomass. The year-lag is given in parentheses

\begin{tabular}{llll}
\hline Biomass of & \multicolumn{2}{l}{ Recruitment of } & \\
\cline { 2 - 4 } & Plaice & Yellowtail & Cod \\
\hline Plaice & $(-2)(-3)-$ & - & $(-1)(0)(1)(2)(3)$ \\
Yellowtail & $(0)(1)(2)$ & - & - \\
Cod & - & - & - \\
Mackerel & $(0)(1)(2)$ & - & - \\
Redfish & $(1)$ & & \\
\hline
\end{tabular}

Fig. 1. Lag between species A year-class and species B spawning biomass diagram.

Fig. 2. Relationship between yellowtail flounder spawning biomass with a lag of 0 years from American plaice year-class and American plaice recruitment. 
Fig. 3. Relationship between mackerel biomass with a lag of 0 years from American plaice year-class and American plaice recruitment.

Fig. 4. Map illustrating NAFO convention area and 200-mile fishing zone boundaries

Fig. 5. Grand Banks region. (a) Cod spawning distributions during March. (b) Spawning location for four commercial finfish species during April to July. (After Fitzpatrick and Miller, 1979). Dotted lines and number/letter codes indicate NAFO divisions. 